ПРОБЛЕМА РЕАЛІЗАЦІЇ ЗМІШАНОГО НАВЧАННЯ У ЗАКЛАДАХ ВИЩОЇ ОСВІТИ В СУЧАСНІЙ ПЕДАГОГІЧНІЙ ТЕОРІЇ ТА ПРАКТИЦІ: СТАН РОЗРОБЛЕНОСТІ

\title{
THE PROBLEM OF IMPLEMENTATION OF BLENDED LEARNING IN HIGHER EDUCATION INSTITUTIONS IN MODERN PEDAGOGICAL THEORY AND PRACTICE: THE STATE OF DEVELOPMENT
}

УДК 370.01

DOI https://doi.org/10.32843/2663-

$6085 / 2021 / 33-1.24$

\section{Собченко Т.М.,}

канд. пед. наук, доцент, доцент кафредри освітології та інноваційної педагогіки Харківського національного педагогічного університету імені Г.С. Сковороди

\begin{abstract}
Сучасний освітній простір в Україні характеризується реформуванням, модернізацією, розвитком інформаційних технологій, підтримкою інновацій, що вимагає зміни підходу до організації процесу навчання для переходу до нової якості.

у статті проаналізовано стан розробки проблеми змішаного навчання у закладах вищої освіти в сучасній теорії та практиці. Зроблено історичний екскурс для з'ясування витоків дистанційного та змішаного навчання. З'ясовано, що після визнання у 2003 році Американським товариством навчання $і$ розвитку змішаного навчання освітнім трендом і перспективою поширення знань трендів як перспективної стратегії поширення знань у цифрову епоху проблематику змішаного навчання піднімали науковці усього світу. Посилена увага до змішаного навчання також простежується після виходу «Довідника змішаного навчання» К. Бонка та М. Грема у 2006 році. Проаналізовано, що вітчизняні та зарубіжні вчені здійснили наукові розвідки за такими аспектами:

- ґенеза та сутність змішаного навчання;

- класифрікація методів, форм, засобів змішаного навчання;

- виокремлення та впровадження моделей змішаного навчання

- стратегія та перспективи впровадження змішаного навчання у заклади вищої освіти; - аналіз досвіду впровадження змішаного навчання у заклади вищої освіти в зарубіжних країнах;

- аналіз переваг і недоліків реалізації змішаного навчання у період пандемії.

Однак попри посилену увагу науковців до цієі теми не вирішеними залишаються питання розробки дидактичної моделі реалізації змішаного навчання здобувачів гуманітарних спеціальностей, яка б включала в себе цільовий, мотиваційний, змістовний, операційно-діяльнісний, контрольно-оцінюючий компоненти для підвищення якості освіти в закладах вищої освіти, що дозволило б випускникам успішно виконувати свої професійні обов'язки та реалізовуватися у професійній діяльності.

Ключові слова: змішане навчання, заклади вищої освіти, пандемія, стан розробки.
\end{abstract}

The modern educational space in Ukraine is characterized by reforming, modernization, development of information technologies, support of innovations, which requires a change in the approach to the organization of the learning process to the transition to a new quality.

The article analyzes the state of development of the problem of blended learning in higher education institutions in modern theory and practice. A historical excursion was made to find out the origins of distance and blended learning. It was found that after the American Society for Learning and Development of Blended Learning recognized the educational trend and the prospect of spreading knowledge as a promising strategy for spreading knowledge in the digital age in 2003, the issue of blended learning was raised by scientists around the world. Increased attention to blended learning can also be traced to the publication "Handbook of Blended Learning" of K. Bonk and M. Graham's, 2006.

It is analyzed that domestic and foreign scientists have carried out scientific research on the following aspects:

- genesis and essence of blended learning;

- classification of methods, forms, means of blended learning;

- identification and implementation of blended learning models;

- strategy and prospects for the introduction of blended learning in higher education institutions;

- analysis of the experience of introducing blended learning in higher education institutions in foreign countries;

- analysis of the advantages and disadvantages of blended learning during a pandemic. However, despite the increased attention of scientists to this topic, the issues of developing a didactic model of blended learning for humanities students, which would include targeted, motivational, meaningful, operational, control and evaluation components to improve the quality of education in institutions, remain unresolved, the higher education, which would allow graduates to successfully perform their professional duties and be realized in professional activities.

Key words: blended learning, higher education institutions, pandemic, state of development.
Постановка проблеми в загальному вигляді. Система вищої освіти покликана стрімко реагувати на виклики суспільства та на об'єктивні процеси його розвитку. Підвищення вимог до якості освіти є однією 3 ключових позицій реалізації нової освітньої парадигми. Реакція системи вищої освіти полягає в успішному розв'язанні проблем і необхідності відповісти на них. Одним із важ- ливих чинників, врахування якого буде сприяти розв'язанню проблеми розвитку сучасної освіти, $€$ її інформатизація. У зв'язку з цим виникає потреба у концептуально новій моделі освіти, а саме у «відкритій». Поряд із цим у сучасній педагогічній теорії та практиці з'явилися такі моделі навчання: «електронне», «мобільне», «дистанційне», «змішане», «гібридне», «онлайн», «навчання на відстані». 
Виникає потреба у вивченні, аналізі та узагальненні проблеми реалізації змішаного навчання, оскільки саме ця модель затребувана у закладах вищої освіти в усьому світі.

Аналіз останніх досліджень і публікацій. Теоретичні й практичні аспекти використання інфрормаційно-комунікативних технологій в освітньому процесі закладів вищої освіти вивчали В. Биков, О. Буров, О. Глазунова, А. Гуржій, М. Жалдак, Т. Коваль, О. Колгатін, А. Коломієць, М. Лещенко, С. Литвинова, Н. Морзе, Ю. Носенко, Л. Панченко, Є. Полат, О. Співаковський, М. Шишкіна. Питаннями змішаного навчання, а саме науково-методичними підходами, цікавилися вітчизняні науковці В. Бикова, Т. Бодненко, Н. Морзе, Н. Рашевська, С. Семеріков, О. Спірін, Є. Смирнова-Трибульска, А. Стрюк, Ю. Триус і зарубіжні К. Бонк, М. Горн, ч. Ґрехем, М. ґрубер, Ч. Дзіюбан, Г. Маєр, А. Норберг, К. Спрін, Х. Стакер, Б. Хан, Д. Харісон.

Мета статті - розкриття стану розробленості проблеми реалізації змішаного навчання у закладах вищої освіти в сучасній педагогічній теорії та практиці.

Методи дослідження. Для вирішення поставленої мети було застосовано в комплексі такі теоретичні методи дослідження: аналіз педагогічної літератури, систематизація та узагальнення досліджень із проблеми реалізації змішаного навчання у закладах вищої освіти.

Виклад основного матеріалу. Наразі світ накопичив досить значний досвід реалізації відкритого навчання. Роблячи екскурс в історію, слід зазначити, що першими фрормами дистанційного навчання кінця XIX століття було «навчання по переписці» та «кореспондентське навчання», оскільки було започатковано службу поштового зв'язку, за допомогою якої можна було це здійснювати, та завдяки прогресивним ідеям учених, громадських діячів, культурно-просвітницьких громад. Починаючи з 1939 року, заочна фрорма навчання була включена у загальну систему підготовки спеціалістів, а після Великої Вітчизняної війни вона набрала більших обертів за рахунок розширення кількості заочних інститутів та інших вищих навчальних закладів, які мали заочні фракультети.

3 кінця 60-х років XX століття масово з'явилися нові технічні засоби, а саме: звукові додатки, фонохрестоматії, «самовчитель» для вивчення іноземних мов, заочні подорожі. Центральне телебачення транслювало телеуроки (15-20 хвилин згідно шкільної програми) для учнів, телеверсії лекцій (на основі навчальних планів Всесоюзного політехнічного інституту (заочного) для абітурієнтів. Починаючи з 90-х років, з'являються такі перші інфрормаційні та комп'ютерні технології: електромагнітні носії - жорсткі диски, електрона пошта, інтерактивні дошки об'яв, аудіо- та відеозв'язок за допомогою інфрормаційної мережі. Ці можливості дозволили по-новому підійти до вирішення проблем організації навчання. Далі стрімкий розвиток інорормаційних технологій зумовив появу нових видів навчання. Так, було введено у лексикон поняття «комп'ютерне навчання», «дистанційне навчання», «електронне навчання», «гібридне навчання». Поняття "hybrid learning", "technologymediated instruction", "web-enhanced instruction", "mixed-mode instruction" використовувалися у вжитку зарубіжними вченими.

Перше штучне інтерактивне середовище«відеоплейс», кероване комп'ютером, створив у 1974 році М. Крюгер. Одна з перших згадок про систему змішаного навчання з'явилася у пресрелізі компанії ЕРIC Interactive Learning Centers у 1999 році. Зокрема, було зазначено, що «наразі компанія розробила 220 електронних курсів, але незабаром буде пропонувати інтернет-курси 3 використанням власної методики «змішаного навчання». Тобто було запропоновано не лише онлайн-курси, але й курси із застосуванням методології змішаного навчання [1].

В. Гуревич, М. Кадемія, Л. Шевченко на основі аналізу процесу впровадження та використання інформаційно-комунікативних технологій у навчальному процесі виділяють три етапи: електронізація (широке впровадження електронних засобів, обчислювальної техніки в навчальний процес (60-70 роки XX ст.), комп'ютеризація (використання комп'ютерів, програмного забезпечення), інфрорматизація (використання сучасних комп'ютерів, швидкодіючих накопичувачів значної ємності, нових ІКТ, соціальних мереж і сервісів) [2].

Теоретичні та практичні питання реалізації змішаного навчання $€$ об'єктом навчального дискурсу не лише в Україні, але й у всьому світі. Особливо після того, коли Американське товариство навчання і розвитку у 2003 році визнало змішане навчання освітнім трендом і перспективою поширення знань трендів як перспективну стратегію поширення знань у цифрову епоху [3].

У 2006 році було видано «Довідник змішаного навчання», автори якого К. Бонк і М. Грем пропонували визначення «змішаного навчання» як комбінації навчання «віч-на-віч» із навчанням, керованим комп'ютерними технологіями, або «діапазон можливостей, представлених завдяки об'єднанню інтернету й електронних засобів масової інформації із фрормами, які вимагають фрізичної присутності у класі викладача і здобувачів освіти» [4, с. 34]. Цей історичний екскурс дав змогу зрозуміти, що саме з 2006 року термін «змішане навчання» досить широко увійшов у науковий обіг. Цю ж думку висвітлюють у своїх дослідженнях В. Беспалько, К. Бугайчук, В. Кухаренко, Н. Ломоносова, Е. Полат, В. Яворський, М. Ґрубер, Ч. Дзіюбан, К. Крістенсен, Г. Маєр, М. Муре, А. Норберг, К. Спірін, Х. Стакер, Б. Хан, М. Горн та інші. 
Генезис і зміст поняття «змішане навчання», визначень якого у зарубіжному науковому просторі дійшло до кількох десятків, досліджували у своїх працях О. Данишко, Л. Семеновська, Л. Ляхоцька. Авторами було визначено складники, характерні ознаки та рівні практичної реалізації змішаного навчання у практику освітніх закладів. Зарубіжні вчені К. Грехман, С. Алленс, Д. Юре, Д. Сміт, М. Дрісколл, Г. Гарірман, Р. Вьоз, Р. Гаррісон, Ч. Ханука, М. Веркост, М. Горн, Х. Стакер досить глибоко здійснили теоретичний аналіз та аргументували підходи щодо визначення сутності змішаного навчання (Ч. Бонк, Ч. Грехам), досліджували практичні рівні реалізації змішаного навчання.

Традиційні комп'ютерно-орієнтовані активні та інтерактивні методи й фрорми, засоби змішаного навчання розглядали Д. Дубов, М. Ожева, М. Мохова, Ю. Тріус, О. Коротун, П. Дін, М. Стах, Д. Салвестер, Дж. Пир, можливості змішаного навчання в аспекті фрормування комунікативної компетентності (М. Орлова) і як засобу забезпечення інформатизації вищої освіти (Н. Ломоносова), педагогічні й організаційні умови ефективного поєднання очного навчання та застосування технологій дистанційного навчання (Ю. Капустіна), специфріку організації дистанційного навчання студентів з особливими потребами у закладах вищої освіти (І. Делик).

Вітчизняні вчені В. Кухаренко, С. Березенська, К. Бугайчук, Н. Олійник, Т. Олійник, О. Рибалко, Н. Сиротенко, А. Столяревська у колективній монографії «Теорія і практика змішаного навчання» 2016 року розкрили педагогічні аспекти змішаного навчання, а саме: тенденції розвитку освіти, система дистанційного навчання, проектування змішаного навчання, інформаційні технології для підтримки змішаного навчання, методи та моделі, використання гейміфрікації, інструменти. Слід зазначити, що теоретичні та практичні засади змішаного навчання визначено в контексті вивчення технічних дисциплін [5].

Моделі змішаного навчання почали класифікувати у 2012 році зарубіжні педагоги М. Горн і Х. Стейкер за такими навчальними характеристиками: "Rotation Model" (Ротаційна модель), "Station Rotation Model" (Модель зміни станцій), "Lab Rotation Model" (Модель зміни лабораторій), "Flipped Model" (Модель перевернутого навчання), "Individual Rotation Model" (Персоналізована модель), "Flex Model" (Гнучка модель), "Self-Blend Model" (Модель самостійного змішування), "Enriched Virtual Model" (Віртуально-збагачена модель). Пізніше ці моделі модифікували залежно від закладу освіти та його матеріально-технічної бази, напряму навчання, фракультету, спеціальності, навчальної дисципліни, вікових особливостей.

Аналізуючи та узагальнюючи наукові розвідки вчених-практиків у цьому аспекті (Н. Андрєєвої,
Г. Кондакова, В. Кухаренка, М. Любомирської, Л. Луцевич, Д. Оськіна, А. Оськіна, К. Лісецького, А. Марголіса, Л. Різдвяної, Б. Ярмах, М. Горна, Х. Стейкера, Г. Ткачук та інших), слід зазначити, що реалізація визначених моделей змішаного навчання більше простежується під час вивчення точних наук: «Математика», «Фізика», «Інорорматика», «Логіка» та інших, ніж гуманітарного спрямування.

Стратегії впровадження змішаного навчання в освітню діяльність закладів вищої освіти розглядали у свої роботах В. Бикова, В. Гогунський (елементи змішаного навчання у процесі викладання навчальних дисциплін), К. Бугайчук, А. Фандєєв, М. Громяк, Я. Василенко, В. Галан, В. Чорний (перспективи застосування та використання у практиці закладів вищої освіти), М. Желуденко, А. Сабітова, С. Семеріков, Н. Рашевська, Д. Пейнтер, Д. Кларк, П. Віліатан, Р. Шанк, Е. Роззетт (практичний аспект використання інформаційнокомунікаційних технологій як перспективний вектор змішаного навчання), Р. Гуревич, М. Кадемія, Л. Шевченко (методика впровадження інформаційно-комунікаційних технологій), Т. Бодненко, В. Кухаренко, С. Касьян, Л. Ляхоцька, Л. Бондаренко, М. Кадемія, О. Спірін, Ю. Тріус, Є. Смирнова-Трибульська, І. Івженко, І. Сокол, В. Кочина, М. Носкова (використання дистанційних фрорм у процесі навчання), В. Ланських, В. Лукін, М. Миклюк, Н. Морзе, В. Свиридюк (питання проєктування змішаного навчання та методики його реалізації), О. Коротун, М. Львов, К. Лісецький (методологічні засади змішаного навчання у закладах вищої освіти). Дослідження досвіду реалізації змішаного навчання в США, Іспанії, Австралії, Китаї, Тайвані, Росії здійснені у роботах Т. Азіатцевої, Г. Ткачук, Г. Кречетнікова, Н. Ломоносової, Т. Носкової, Т. Павлової, О. Яковлєвої, Н. Захарової, А. Юдінцової та інших.

В умовах пандемії та вимушеного карантину, коли змішане навчання було впроваджено в усі заклади освіти майже у 200 країнах світу, з'явилася чимала кількість публікацій на сторінках педагогічної преси й на сторінках інорормаційного простору мережі Інтернет. Педагоги, психологи, науковці, освітяни, експерти висловлювали своє бачення щодо вирішення проблеми реалізації змішаного навчання у закладах вищої освіти. Коронакриза показала, що у майбутньому дистанційна освіта, змішане навчання стануть складниками звичайного освітнього процесу попри недоліки, труднощі та бар'єри, які виникали. Особливості реалізації змішаного навчання в умовах карантину аналізували та узагальнювали Р. Азаві, В. Бикова, Ч. Уелт, О. Курок, Г. Лученко, О. Повстун, О. Луценко, С. Волошинов, В. Круглик, В. Осадчий, К. Осадча, С. Симоненко) $[6 ; 7 ; 8]$ та інші вітчизняні й зарубіжні науковці. 
Висновки. Отже, проблема реалізації змішаного навчання у закладах вищої освіти в сучасній педагогічній теорії та практиці наразі актуальна попри те, що їі витоки сягають у минуле століття. Вітчизняними та зарубіжними вченими здійснено такі наукові розвідки:

- розкрито ґенезу та сутність змішаного навчання;

- досліджено методи, фрорми, засоби;

- розроблено моделі змішаного навчання;

- вибудувано стратегію та перспективи впровадження змішаного навчання у заклади вищої освіти;

- вивчено та узагальнено досвід впровадження змішаного навчання у заклади вищої освіти в зарубіжних країнах;

- здійснено аналіз переваг і недоліків реалізації змішаного навчання у період пандемії.

Однак попри посилену увагу науковців до цієї теми не вирішеними залишаються питання розробки дидактичної моделі реалізації змішаного навчання для підвищення якості освіти в закладах вищої освіти, що дозволить їхнім випускникам успішно виконувати свої професійні обов'язки та реалізовуватися у професійній діяльності.

\section{БІБЛІОГРАФІЧНИЙ СПИСОК:}

1. Garrison D. Blended learning in higher education: Framework, principles and guidelines Jossey-Bass.
2008. 272 p. Friesen Norm Report: Defining Blended Learning. URL: https://www.normfriesen.info/papers/ Defining_Blended_Learning_NF.pdf.

2. Гуревич Р.С. Інформаційні технології навчання: інноваційний підхід : навчальний посібник / за ред. Гуревича Р.С. Вінниця : ТОВ фрірма «Планер», 2012. 348 c.

3. Rooney J. Blending learning opportunities to enhance educational programming and meetings. Association Management, vol. 55 (5), 2003. P. 26-32.

4. Bonk C.J. The Handbook of Blended Learning: Global erspectives, Local Designs / Bonk C.R., Graham M.G. Moore. Pfeiffer, 2006. 624 p.

5. Теорія та практика змішаного навчання : монограсрія / В.М. Кухаренко та ін. Харків, 2016. 284 с.

6. Kurok O., Lucenko G., Povstyn O., Lutsenko O. Features of distance education in ukraine during the Covid-19 pandemic: problems and prospects Universal Journal of Educational Research, 2020. 8(11). P. 5498-5504.

7. Волошинов С., Круглик В., Осадчий В., Осадча К., Симоненко С. Реалии и перспективы дистанционного обучения в высших учебных заведениях Украины. Украинский журнал образовательных исследований и инфрормационных технологий, 2020. 8(1). C. 1-16.

8. Azawi R., Al-Obaidy M., Qaddoum K. "Mobile Augmented Reality (MAR) in Distance Learning: Present and Future", 2020. Seventh International Conference on Information Technology Trends (ITT). Abu Dhabi : United Arab Emirates, 2020. P. 140-145, doi: 10.1109/ ITT51279.2020.9320889. 